\title{
Exploring Possible Missing Sinks of Nitrate and Its Precursors in Current Air Quality Models -A Case Simulation in the Pearl River Delta, China, Using an Observation-Based Box Model
}

\author{
Jie $\mathrm{Li}^{1}$, Huabin Dong ${ }^{1,2}$, Limin Zeng ${ }^{2}$, Yuanhang Zhang ${ }^{2}$, Min Shao ${ }^{2}$, Zifa Wang ${ }^{1,2}$, Yele Sun ${ }^{1}$ and Pingqing Fu ${ }^{1}$ \\ ${ }^{1}$ LAPC, Institute of Atmospheric Physics, Chinese Academy of Sciences, Beijing, China \\ ${ }^{2}$ Peking University, Beijing, China
}

\begin{abstract}
Nitrate and its precursor (gaseous $\mathrm{HNO}_{3}$ ) in China are generally overestimated by current chemical transport models in comparison to in-situ observations. In this study, we used an observation-based box model and in-situ measurements at a rural site in southern China to investigate possible missing sinks of nitrate. We found that a heterogeneous reaction of $\mathrm{HNO}_{3}$ to $\mathrm{NO}_{\mathrm{x}}$ on soot can better balance the $\mathrm{NO}_{\mathrm{x}} / \mathrm{HNO}_{3}$ chemistry in models and improve model performance with regard to nitrate, particularly where an additional $\mathrm{HONO}$ source (the heterogeneous reaction of $\mathrm{NO}_{2}$ on soot) is incorporated into current models. Through a series of sensitivity simulations, the uptake coefficients of heterogeneous reactions were suggested to be $3.0 \times 10^{-3}$ and $1 \times 10^{-4}$ for $\mathrm{HNO}_{3}$ and HONO over southern China in fall, respectively. A 3-D simulation with the suggested uptake coefficients further confirmed that heterogeneous reactions significantly decreased the nitrate concentrations $\left(\mathrm{PNO}_{3}\right)$ in southern China, by up to $10 \mu \mathrm{g} \mathrm{m} \mathrm{m}^{-3}(50 \%-80 \%$ of simulated $\mathrm{PNO}_{3}$ ) in polluted regions (e.g., the Yangtze River). In contrast to nitrate and $\mathrm{HNO}_{3}, \mathrm{NO}_{\mathrm{x}}$ concentrations in China were enhanced, which partly explained the underestimation of $\mathrm{NO}_{2}$ in current models compared to satellite observations.
\end{abstract}

(Citation: Li, J., H. B. Dong, Z. F. Wang, Yele Sun, and Pingqing $\mathrm{Fu}, 2015$ : Exploring possible missing sinks of nitrate and its precursors in current air quality models - A case simulation in Pearl River delta of China using an observation-based box model. SOLA, 11, 124-128, doi: 10.2151/sola.2015-029.)

\section{Introduction}

There is growing concern over the role of nitrate aerosol in the increasingly common haze episodes in China (Jansen et al. 2014). However, recent simulations including the GEOS-Chem, CHASER and CMAQ models, have greatly overestimated nitrate levels in China, with predicted levels reaching four times of the observed annual concentration (Sudo et al. 2002; Kim et al. 2006; Wang et al. 2013). This suggests shortcomings in our current understanding of nitrogen oxides $\left(\mathrm{NO}_{\mathrm{x}}\right)$ cycle and related processes. Recently, sporadic observations in China have suggested that the overestimation of gaseous nitric acid $\left(\mathrm{HNO}_{3}\right)$ in models might be the cause of the high nitrate levels in simulations. Li et al. (2015) simulated summer $\mathrm{HNO}_{3}$ in Beijing using WRF-Chem and predicted levels in the range $2-5$ parts per billion by volume (ppbv), which was much higher than observations $(0-1 \mathrm{ppbv})$. Similar results were also found in the northwestern Pacific, where simulated $\mathrm{HNO}_{3} / \mathrm{NO}_{\mathrm{x}}$ and peroxy acetyl nitrate $(\mathrm{PAN}) / \mathrm{NO}_{\mathrm{x}}$ were found to be 2-3 times higher than observations during the Transport and Chemical Evolution over the Pacific (TRACE-P) campaign (Talbot et al. 2003). Tang et al. (2014) warned that if new additional sources of nitrous acid (HONO) were incorporated into current

Corresponding author: Huabin Dong, Institute of Atmospheric Physics, Chinese Academy of Sciences, 40\# Huayanbeili, Chaoyang District, Beijing 100029, China. E-mail: Donghb@mail.iap.ac.cn. C2015, the Meteorological Society of Japan. models, simulated nitrate levels would increase by $80 \%-100 \%$ in China. Hence, a better understanding of the atmospheric chemistry of $\mathrm{HNO}_{3}$ and its related reactive nitrogen-containing gases (e.g., nitrous acid) in current models is key to reproducing the evolution of nitrate on haze days.

Both dry/wet deposition and ammonia emissions could explain this overestimation of nitrate (Shimadera et al. 2014). However, neither process can completely explain why there has been such a large overestimation of the monthly mean gaseous $\mathrm{HNO}_{3}$ and $\mathrm{HNO}_{3} / \mathrm{NO}_{\mathrm{x}}$ under the $\mathrm{NO}_{\mathrm{x}}$ underestimation over China and northwestern Pacific. Recently, a heterogeneous reaction of $\mathrm{HNO}_{3}$ on soot (R1) was proposed to explain the overestimation of $\mathrm{HNO}_{3}$ / $\mathrm{NO}_{x}$ in simulations (Rogasi et al. 1997). This mechanism has been successfully applied in some studies, although it has still to be confirmed in laboratory studies (Hauglustaine et al. 1996; Kleffmann and Wiesen 2005). Many uptake coefficients for R1 $\left(\gamma_{\mathrm{HNO}_{3}}\right)$, ranging from $10^{-7}$ to $10^{-2}$, have been proposed based on laboratory and model experiments (Hauglustaine et al. 1996; Rogasi et al. 1997), and therefore studies of $\gamma_{\mathrm{HNO}_{3}}$ that are appropriate for the soot aerosol morphology in China are needed.

$$
\begin{aligned}
& \mathrm{HNO}_{3}+\text { soot } \rightarrow \mathrm{NO}+\mathrm{NO}_{2} \\
& \mathrm{NO}_{2}+\text { soot } \rightarrow 0.5 \mathrm{HONO}+0.5 \mathrm{HNO}_{3}
\end{aligned}
$$

The heterogeneous reaction for HONO formation (R2) does greatly affect the nitrate concentration (Tang et al. 2014). Unfortunately, there have been few studies of the uptake coefficient of $\mathrm{R} 2\left(\gamma_{\text {HONO }}\right)$ in China (Li et al. 2012b). Tang et al. (2014) reported a suggested $\gamma_{\text {HONO }}$ of $10^{-4}$ for the North China Plain, but this has not been tested in other regions in China.

In this study, we utilized an observation-based box model to estimate possible $\gamma_{\mathrm{HNO}_{3}}$ and $\gamma_{\mathrm{HONO}}$ that were appropriate for the soot morphology in southern China, which was expected to reduce the impacts of uncertainties resulting from the emission inventory. A 3-D chemical transport model was used to assess the regional-scale impact of heterogeneous reactions (R1 and R2) on atmospheric chemistry in southern China. The observations were taken from an integrated field campaign (Synthesized Prevention Techniques for Air Pollution Complex and Integrated Demonstration in Key City-Cluster Region: 3C-star) in the Pearl River Delta, China (Zhang 2009b).

\section{Methodology}

\subsection{Sampling site and measurement technique}

The measurements were made at a typical rural supersite (Kaiping, $22.32^{\circ} \mathrm{N}, 112.53^{\circ} \mathrm{E}$; Fig. S1 in the supplement) about $120 \mathrm{~km}$ southwest of Guangzhou, a megacity in southern China. The 3C-star field campaign was conducted from 2008-10-15 to 2008-11-19, and involved more than 100 researchers from 12 research institutes. As one of two super sites, various gaseous $\left(\mathrm{HNO}_{3}\right.$, $\mathrm{HONO}$, sulfur dioxide/ $\mathrm{SO}_{2}, \mathrm{NO}_{\mathrm{x}}$ and volatile organic compounds/ VOCs) and aerosol pollutants were measured in Kaiping. A strict QA/QC procedure was performed, with details provided in Cheng et al. (2013). In this study, the period of 2008-10-28 to 2008-1031 was selected because of the low wind velocity (mean value: $1.5 \mathrm{~m} \mathrm{~s}^{-1}$ and maximum: $<3.5 \mathrm{~m} \mathrm{~s}^{-1}$ ) and wet weather (mean rela- 
tive humidity: $80 \%$; minimum: $60 \%$ ) (Fig. S2 in the supplement). These meteorological conditions are favorable to the heterogeneous reactions on soot.

Hourly concentrations of gaseous $\mathrm{HNO}_{3}, \mathrm{HONO}, \mathrm{SO}_{2}$, and inorganic aerosols (sulfate, nitrate, chloride, and ammonium) were measured by a Gas and Aerosol Collector with Ion-exchange Chromatography (GAC-IC) system developed by Dong et al. (Dong et al. 2012). An intercomparison of the GAC-IC and the TE 43c analyzer (for $\mathrm{SO}_{2}$ ), LOng Path Absorption Photometer (LOPAP, for HONO), a filter-based method, and the Aerosol Mass Spectrometer (AMS, for inorganic aerosols) at Kaiping suggested a good consistency throughout the 3C-star campaign (Dong et al. 2012). Levels of $\mathrm{CO}, \mathrm{O}_{3}$, and soot were measured by commercial instruments (Thermo Electron, Model 48C, 49C, and MAAP Model 5012, respectively). Levels of $\mathrm{NO} / \mathrm{NO}_{2}$ were measured with a photolytic chemiluminescence $\mathrm{NO}_{\mathrm{x}}$ analyzer (Cheng et al. 2013). Aerosol extinction was measured by an integrating nephelometer. Two two online GC-FID/PID systems (Syntech Spectra GC-FID/PID GC955 series 611/811 VOC analyzer), one for the C3-C5 NMHCs, and the other for C6-C9 NMHCs were used to measure $\mathrm{C} 3-\mathrm{C} 9 \mathrm{NMHCs}$ concentrations with a time resolution of $30 \mathrm{~min}$ (Shao et al. 2009).

\subsection{Box modeling calculations \\ a. Box model description}

An integrated modular box model was used in this study, which had previously been successfully used to simulate atmospheric oxidation in Beijing during the 2008 Olympics ( $\mathrm{Li}$ et al. 2011). In this box model, CBM-Z with 133 reactions, RADM, and ISORROPIAv1.7 were used to reproduce the gas, aqueous, and inorganic aerosol chemical processes in the atmosphere, respectively. An accurate radiative transfer model (TUV 4.5) was used to calculate on-line photolysis frequencies, considering the impact of clouds and aerosols. The heterogeneous chemistry module was updated to 28 reactions on four types of aerosols (soot, sulfate, dust, and sea salt) from eight reactions on two types of aerosol in Li et al. (2011) (Table S1 in the supplement). The dry deposition velocity of $\mathrm{HNO}_{3}$ was set to $2 \mathrm{~cm} \mathrm{~s}^{-1}$, in accordance with previous observations (Adon et al. 2013).

The observed hourly gaseous species $\left(\mathrm{CO}, \mathrm{O}_{3}, \mathrm{SO}_{2}, \mathrm{NO} / \mathrm{NO}_{2}\right.$, $\mathrm{NH}_{3}$, and $\mathrm{C}_{2}-\mathrm{C}_{12}$ VOCs), aerosols (sulfate, nitrate, ammonium, chloride and soot), aerosol optical depth, boundary layer height, water vapor, ambient temperature, and pressure were averaged or interpolated with a time resolution of $5 \mathrm{~min}$, and used as model constraints. Aerosol Surface Area (SA) was calculated from the observed aerosol mass concentrations. We assumed that aerosols were spherical, and the mean radius and mass density of sulfate and soot were taken from Tie et al. (2005) (sulfate: $0.24 \mu \mathrm{m}, 1.7 \mathrm{~g} \mathrm{~cm}^{-3}$; soot: $0.04 \mu \mathrm{m}, 1.0 \mathrm{~g} \mathrm{~cm}^{-3}$ ), with a lognormal distribution. Dust and sea salts were divided into 4 bins $(0-1 \mathrm{~m}$; $1-2.5 \mathrm{~m}, 2.5-5 \mathrm{~m}, 5-10 \mathrm{~m}$ ), with mass density of $2.2 \mathrm{~g} \mathrm{~cm}^{-3}$ and $2.65 \mathrm{~g} \mathrm{~cm}^{-3}$, respectively. Observations of $\mathrm{HNO}_{3}$ and $\mathrm{HONO}$ were only used to evaluate model performance in different scenarios, without inputting the box model.

\section{b. Model setup}

A series of sensitivity simulations were designed to obtain suitable uptake coefficients for southern China. In these simulations, the ranges of $\gamma_{\mathrm{HNO}_{3}}$ and $\gamma_{\mathrm{HONO}}$ were $0 \sim 1 \times 10^{-1}$ and $0 \sim 1 \times$ $10^{-2}$ with intervals of $1 \times 10^{-5}$, respectively. The values in which simulated $\mathrm{HNO}_{3}$ and $\mathrm{HONO}$ were the closest (the smallest root mean square error) to observations were regarded as suitable uptake coefficients.

The model calculation was made for each day over the period of 2008-10-28 to 2008-10-31. The time of 00:00 LST was regarded as the initial time for each day. This integration was conducted three times to stabilize the concentrations of unconstrained species. The results calculated for the last $24 \mathrm{~h}$ were used as the output. The emission rates of several species were taken from Zhang et al. (2009a). Additional loss by deposition, with a corresponding lifetime of three days, was assumed to prevent the buildup of unrealistic amounts of secondary products.

\section{Results and discussion}

3.1 Observed levels of gaseous $\mathrm{HONO}, \mathrm{HNO}_{3}$, and $\mathrm{NO}_{x}$ at Kaiping

Figure 1 shows the observed hourly gaseous $\mathrm{HONO}, \mathrm{HNO}_{3}$, $\mathrm{NO}_{\mathrm{x}}, \mathrm{HNO}_{3} / \mathrm{NO}_{\mathrm{x}}$, and black carbon (BC) at Kaiping during 200810-28 to 2008-10-31. Due to photolysis, the observed HONO reached its maximum $(\sim 1 \mathrm{ppbv})$ in the nighttime and fell back to the minimum ( $\sim 0.2 \mathrm{ppbv})$ when the sun was overhead. Compared with $\mathrm{HONO}$, gaseous $\mathrm{HNO}_{3}$ displayed the reverse pattern, with a daytime maximum of 5-6 ppbv. The daytime HONO at Kaiping was similar to summertime observations at suburban sites in other megacities in China (e.g., Beijing and Shanghai), but was slightly higher than those in summer and winter at European and US suburban sites (Li et al. 2015; Michoud et al. 2014). Gaseous $\mathrm{HNO}_{3}$ at Kaiping was almost 3-4 times higher than levels reported in California and Mexico City where the diurnal maximum in spring and summer was usually 1 ppbv (Day et al. 2009; Zheng et al. 2008). The hourly $\mathrm{HNO}_{3} / \mathrm{NO}_{x}$ ratio was in the range $0.02-1.3$, with a mean of 0.13 , much less than observations in aged plumes over remote regions (average $\sim 5$ ) (Chatfield 1994). This indicated that levels in Kaiping were controlled by fresh plumes rather than aged plumes. $\mathrm{BC}$ concentrations ranged from $1-5 \mu \mathrm{g} \mathrm{m}^{-3}$, with a mean of $2.2 \mu \mathrm{g} \mathrm{m}^{-3}$, which provided an abundant surface area for heterogeneous reactions ( $\mathrm{R} 1$ and $\mathrm{R} 2)$.

\subsection{The uptake coefficients for heterogeneous reactions ( $R 1$ and R2) suggested by the box model}

Figure 2 shows the simulated gaseous $\mathrm{HONO}, \mathrm{HNO}_{3}$, and $\mathrm{HNO}_{3} / \mathrm{NO}_{\mathrm{x}}$ in the box model sensitivity simulations. As expected, both simulated $\mathrm{HONO}$ and $\mathrm{HNO}_{3}$ displayed a large discrepancy with the observations in current models without R1 and R2 (i.e., $\gamma_{\mathrm{HONO}}$ and $\gamma_{\mathrm{HNO}_{3}}$ were set to 0 ). The simulated mean $\mathrm{HNO}_{3}$ was $2.1 \mathrm{ppbv}$ in the whole period, $57 \%$ higher than observations $(1.3$ ppbv). This systematic overestimation was $\sim 2-3$ times higher than the observed values during the daytime. Consequently, an overestimation of $\mathrm{HNO}_{3} / \mathrm{NO}_{\mathrm{x}}$ is apparent in Fig. 2. During the daytime on $31^{\text {th }}$, the simulated $\mathrm{HNO}_{3} / \mathrm{NO}_{\mathrm{x}}$ ratio was four, while the observation was only $\sim 1$. Levels of HONO were significantly underestimated without an additional source (R2), which was previously reported by $\mathrm{Li}$ et al (2015). We selected uptake coefficients for $\mathrm{R} 1$ and $\mathrm{R} 2$ in which simulated $\mathrm{HNO}_{3}$ and $\mathrm{HONO}$ were closest to the observations. As shown in Fig. 2, a $\gamma_{\mathrm{HNO}_{3}}$ of $3.0 \times$ $10^{-3}$ and $\gamma_{\text {HONO }}$ of $1 \times 10^{-4}$ were suggested for southern China in this study. The simulated mean $\mathrm{HNO}_{3}$ and HONO for the suggested uptake coefficients were $1.29 \mathrm{ppbv}$ and $0.36 \mathrm{ppbv}$, respectively, which were close to observations $\left(\mathrm{HNO}_{3}\right.$ : 1.30 ; HONO: 0.43 ppbv). The suggested $\gamma_{\mathrm{HNO}_{3}}$ was quite similar to that used in a labo-

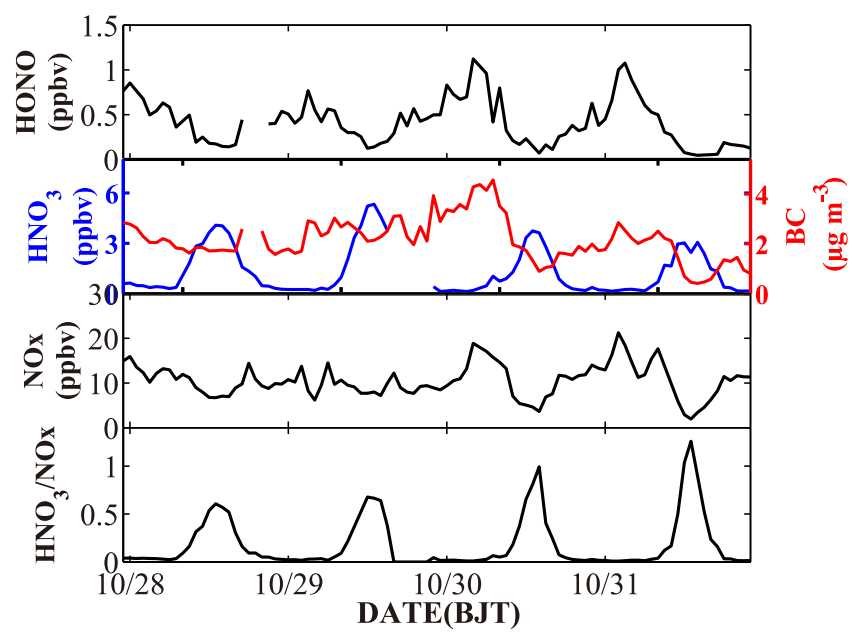

Fig. 1. Observed hourly gaseous $\mathrm{HONO}, \mathrm{HNO}_{3}$, and $\mathrm{NO}_{\mathrm{x}}$ (ppbv), and black carbon $\left(\mu \mathrm{g} \mathrm{m}^{-3}\right)$ at Kaiping during 2008-10-28 to 2008-10-31. The $\mathrm{HNO}_{3} / \mathrm{NO}_{\mathrm{x}}$ ratio is also shown. 


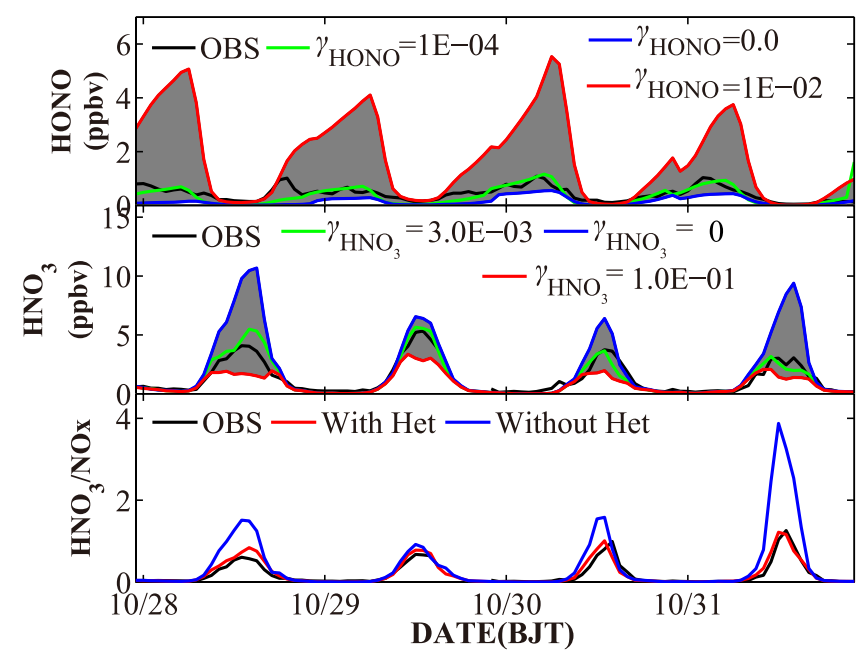

Fig. 2. Comparison between observed and simulated $\mathrm{HONO}, \mathrm{HNO}_{3}$, and $\mathrm{HNO}_{3} / \mathrm{NO}_{\mathrm{x}}$ in sensitivity simulations with different uptake coefficients for R1 and R2 in the box model at Kaiping during 2008-10-28 to 2008-10-31. The gray shaded area is the range of simulated $\mathrm{HONO}$ and $\mathrm{HNO}_{3}$.

ratory study by Muñoz et al. (2002), in which $4.6 \pm 1.6 \times 10^{-3}$ was obtained by experiments based on a Knudsen cell. Compared with other modeling study $\left(3.0 \times 10^{-7}\right)$ by Saathoff et al. (2001), our suggested $\gamma_{\mathrm{HNO}_{3}}$ was higher. This implied that previous simulations likely underestimated the impact of heterogeneous reactions on nitrate simulation on China.

Note that the observed daytime HONO was still underestimated using the suggested $\gamma_{\text {HONO }}$, which is likely to be because unknown additional sources depending on $\mathrm{NO}_{2}$ photolysis rates was not included in this study ( $\mathrm{Li}$ et al. 2015).

\subsection{Regional impact of heterogeneous reactions ( $R 1$ and $R 2)$ on atmospheric chemistry in southern China}

In this study, to assess the regional impact of heterogeneous reactions (R1 and R2) on nitrate chemistry in southern China, we used a 3-D chemical transport model (NAQPMS) developed by the Institute of Atmospheric Physics, Chinese Academy of Sciences, using the suggested $\gamma_{\mathrm{HONO}}$ and $\gamma_{\mathrm{HNO}_{3}}$. NAQPMS has been widely used to simulate dust events, acid deposition, ozone, and aerosols in East Asia. A detailed description of the model is provided in Li et al. (2012a). Four simulations (S1: without R1 and R2; S2: with the suggested $\gamma_{\mathrm{HNO}_{3}}$, but without $\gamma_{\mathrm{HONO}}$; S3: with the suggested $\gamma_{\mathrm{HONO}}$, but without $\gamma_{\mathrm{HNO}_{3}}$; and S4: with the suggested $\gamma_{\mathrm{HNO}_{3}}$ and $\gamma_{\mathrm{HONO}}$ ) were conducted based on the 2006 Multi-resolution Emission Inventory for China (INTEX-B) emissions prepared by Zhang et al. (2009a) at a $45 \mathrm{~km}$ resolution.

As shown in Fig. 3, heterogeneous reactions significantly improved the predicted accuracy of NAQPMS. The heterogeneous reaction R1 decreased the simulated average gaseous $\mathrm{HNO}_{3}$ from 3.8 to $1.7 \mathrm{ppbv}$. The conversion from $\mathrm{HNO}_{3}$ to $\mathrm{NO}_{x}$ by $\mathrm{R} 1$ increased the simulated $\mathrm{NO}_{\mathrm{x}}$ from 7.4 to $12.7 \mathrm{ppbv}$, which was closer to the observed value $(10.7 \mathrm{ppbv})$. The simulated $\mathrm{PNO}_{3}$ also decreased from $\sim 9 \mu \mathrm{g} \mathrm{m}^{-3}$ to $\sim 6 \mu \mathrm{g} \mathrm{m}^{-3}$, close to observations $\left(4.8 \mu \mathrm{g} \mathrm{m}^{-3}\right)$. An overestimation of $\mathrm{NO}_{\mathrm{x}}$ was apparent around noontime (4:00-8:00 UTC), which was likely caused by the underestimation of vertical turbulence. The model in S4 with R2 also succeeded in capturing the magnitude of observed HONO peaks during the nighttime $(\sim 1 \mathrm{ppbv})$.

Figure 4 shows the spatial distribution of simulated gaseous $\mathrm{HNO}_{3}, \mathrm{HONO}, \mathrm{NO}_{\mathrm{x}}$, and $\mathrm{PNO}_{3}$ with $\mathrm{R} 1$ and $\mathrm{R} 2$ in southern China. The highest $\mathrm{HNO}_{3}$ concentration appeared to the north of Guangzhou, with a magnitude of 4 ppbv. Kaiping station was located on the southern rim of the high concentration belt. Nitrate oncentrations were more uniformly distributed over the land with a range of 6-9 $\mu \mathrm{g} \mathrm{m}^{-3}$, while the maximum values were in areas along the Yangtze River $\left(15 \mu \mathrm{g} \mathrm{m}^{-3}\right)$. The high nitrate along Yangtze River

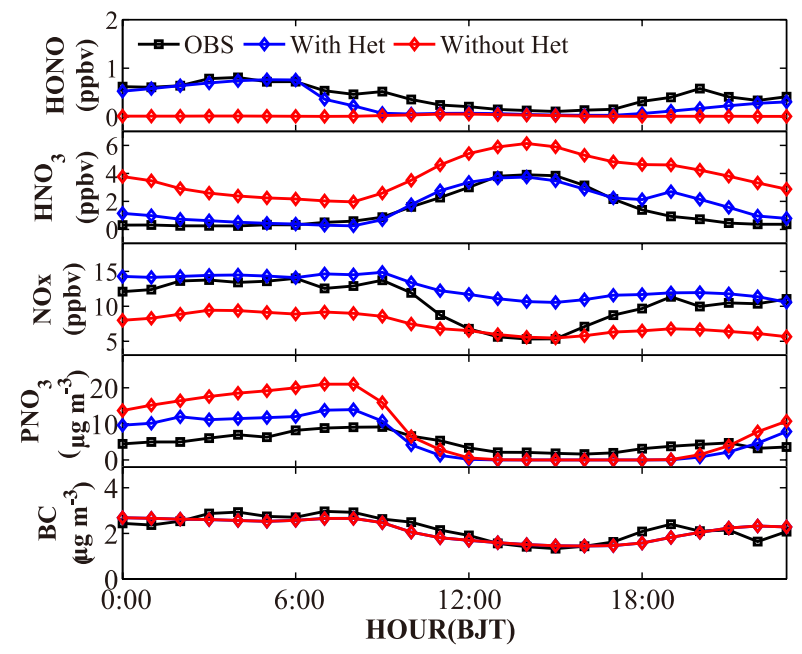

Fig. 3. Comparison between observed and simulated diurnal averages of $\mathrm{HONO}, \mathrm{HNO}_{3}, \mathrm{NO}_{x}, \mathrm{PNO}_{3}$ and $\mathrm{BC}$ in NAQPMS using the suggested uptake coefficients at Kaiping during 2008-10-28 to 2008-10-31.
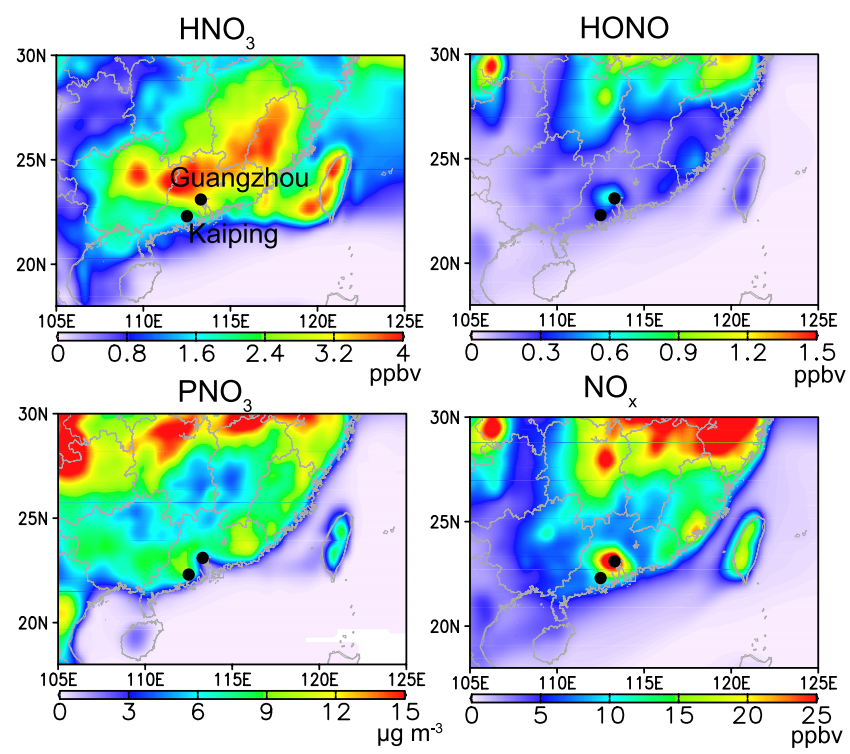

Fig. 4. Spatial distribution of simulated surface $\mathrm{HNO}_{3}, \mathrm{HONO}, \mathrm{PNO}_{3}$, and $\mathrm{NO}_{x}$ in southern China during 2008-10-28 to 2008-10-31. The locations of Guangzhou and Kaiping are also shown.

was likely caused by the lower temperature. Compared with $\mathrm{HNO}_{3}$ and $\mathrm{PNO}_{3}$, high levels of $\mathrm{NO}_{\mathrm{x}}$ and $\mathrm{HONO}$ were limited near to the locations of $\mathrm{NO}_{\mathrm{x}}$ emissions.

Figure 5 shows the regional impact of R1 and R2 in southern China in the studying period. Clearly, nitrate concentrations significantly decreased in the modeling domain due to the heterogeneous reactions. The largest decrease occurred in the middle and lower reaches of the Yangtze River $\left(25^{\circ} \mathrm{N}-30^{\circ} \mathrm{N}, 110^{\circ} \mathrm{E}-120^{\circ} \mathrm{E}\right)$, with a magnitude of $10 \mu \mathrm{g} \mathrm{m}^{-3}\left(50 \%-80 \%\right.$ of simulated $\mathrm{PNO}_{3}$ in S4) (Fig. 5g). At Kaiping, $\mathrm{PNO}_{3}$ decreased by $1-3 \mu \mathrm{g} \mathrm{m}^{-3}(10 \%-$ $30 \%$ ). Note that the decrease was $30 \%-80 \%$ over coastal waters along the continent, which was likely a result of the low simulated $\mathrm{PNO}_{3}$ concentrations. This overall decrease of $\mathrm{PNO}_{3}$ was mostly caused by $\mathrm{R} 1$ instead of R2 (Fig. 5h). In R2, more $\mathrm{NO}_{2}$ was converted to $\mathrm{HONO}$, which yielded more $\mathrm{OH}$. This increased the $\mathrm{HNO}_{3}$ and $\mathrm{PNO}_{3}$ concentrations through the reactions of $\mathrm{NO}_{2}+$ $\mathrm{OH} \rightarrow \mathrm{HNO}_{3}$ and $\mathrm{HNO}_{3}+\mathrm{NH}_{3} \leftrightarrow \mathrm{NH}_{4} \mathrm{NO}_{3}$ (Fig. 5i). R1 and R2 had the opposite effect on $\mathrm{PNO}_{3}$, which suggested that R1 must be coupled into current models in cases where R2 is included (Li 


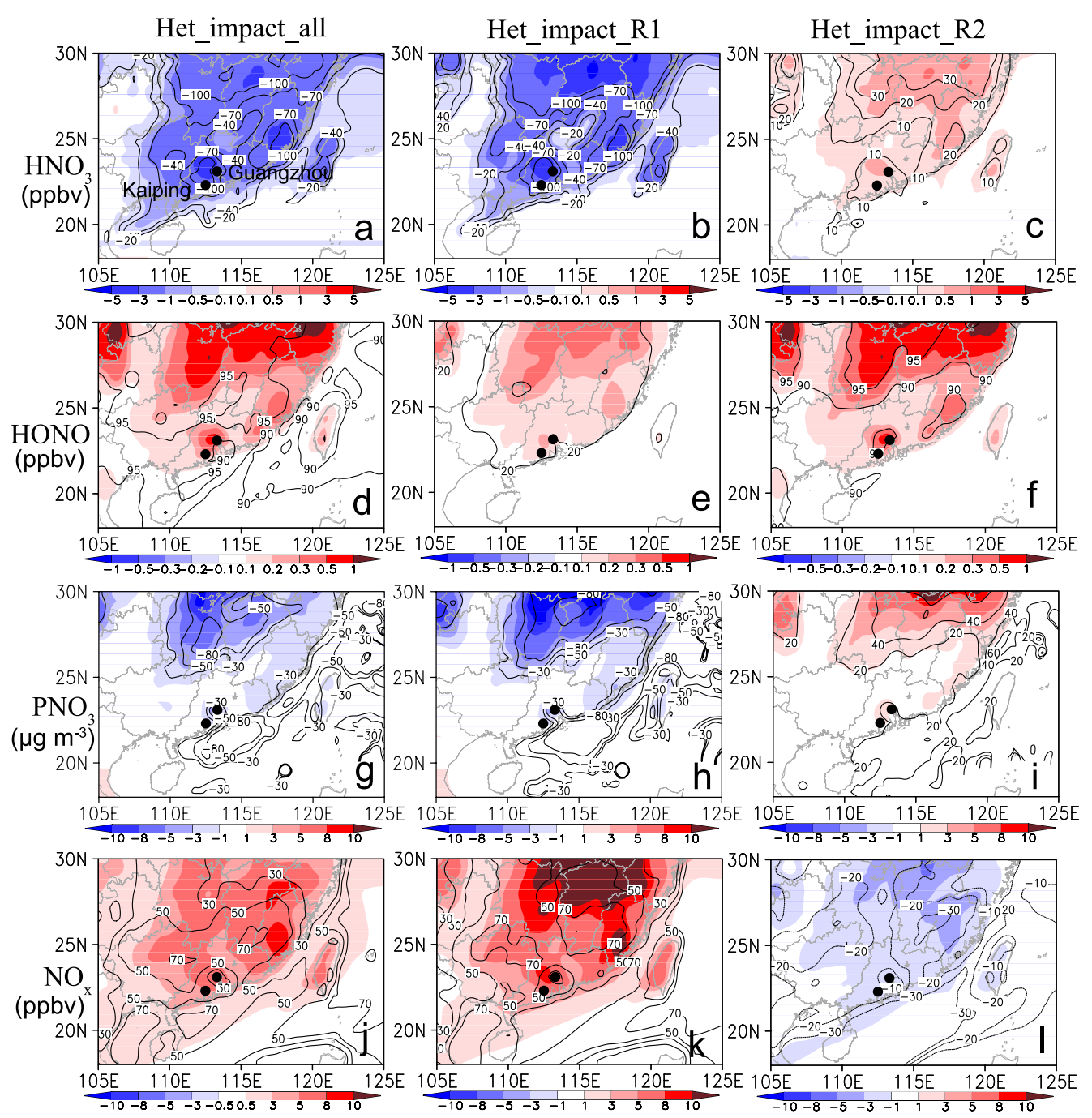

Fig. 5. Regional impact of heterogeneous reactions (R1 and R2) on gaseous $\mathrm{HNO}_{3}, \mathrm{HONO}, \mathrm{PNO}_{3}$, and $\mathrm{NO}_{\mathrm{x}}$ in southern China during 2008-10-28 to 200810-31 (shaded: ppbv or $\mu \mathrm{g} \mathrm{m}^{-3}$; contour: \%). The left, middle, and right columns represent the overall (Het_impact_all), R1 (Het_impact_R1), and R2 (Het_ impact_R2) effects, respectively. The first, second, third and fourth line represent impacts on $\mathrm{HNO}_{3}, \mathrm{HONO}, \mathrm{PNO}_{3}$ and $\mathrm{NO}_{x}$.

et al. 2015), to avoid a larger overestimation of nitrate.

Similar as $\mathrm{PNO}_{3}$, there was an overall negative effect of $\mathrm{R} 1$ and $\mathrm{R} 2$ on the $\mathrm{HNO}_{3}$ concentration (Fig. 5a), although R2 alone slightly enhanced $\mathrm{HNO}_{3}$ by $0.1-1 \mathrm{ppbv}$ in the modeling domain (Fig. 5c). The overall decrease of $\mathrm{HNO}_{3}$ when $\mathrm{R} 1$ and $\mathrm{R} 2$ were included reached 3-5 ppbv over most regions in southern China, which accounted for $70 \%-100 \%$ of the simulated $\mathrm{HNO}_{3}$. The regional impact of $\mathrm{R} 1$ and $\mathrm{R} 2$ on $\mathrm{NO}_{2}$ showed the reverse pattern with $\mathrm{HNO}_{3}$ and $\mathrm{PNO}_{3}$ (Fig. 5j, k, 1). The overall effect of $\mathrm{R} 1$ and $\mathrm{R} 2$ was to increase the $\mathrm{NO}_{2}$ concentrations by $3-8 \mathrm{ppbv}$ $(30 \%-50 \%)$ in southern China, with levels reaching 8 ppbv at Kaiping (Fig. 5j). As shown in Fig. 5h, i, more $\mathrm{HNO}_{3}$ was recycled back to $\mathrm{NO}_{\mathrm{x}}$ by $\mathrm{R} 1$ than $\mathrm{NO}_{\mathrm{x}}$ was lost on soot by $\mathrm{R} 2$ in southern China. This enhancement by $\mathrm{R} 1$ partly explains the underestimation of $\mathrm{NO}_{2}$ in previous simulations without R1 (Han et al. 2015), and could have an important impact on the inverse modeling of $\mathrm{NO}_{2}$ emissions in China. For HONO, the overall enhancement from two heterogeneous reactions reached $0.5-1 \mathrm{ppbv}$ along the Yangtze River (Fig. 5d). In the Pearl River Delta, this enhancement was $0.2-0.5$ ppbv. This enhancement of HONO accounted for more than $90 \%-95 \%$ of simulated HONO in S4, which indicates that heterogeneous chemistry was the dominant source of HONO, rather than the gas chemistry (Li et al. 2015). Among the heterogeneous reactions, R2 produced a more significant HONO enhancement than R1 (Fig. 5e, f).

\section{Conclusion and recommendations}

Nitrate aerosol and its precursor (gaseous $\mathrm{HNO}_{3}$ ) are frequently overestimated over China by current 3-D chemical transport models. In this study, we used an observation-based box model in association with observations at a rural site in the Pearl River Delta of China during 28 to 31 October 2008 to examine the possible causes of this overestimation. We found that a heterogeneous reaction of $\mathrm{HNO}_{3}$ to $\mathrm{NO}_{\mathrm{x}}$ on soot tends to better balance the $\mathrm{NO}_{\mathrm{x}} /$ $\mathrm{HNO}_{3}$ chemistry in models and improve model performance with regard to nitrate. The previously reported heterogeneous reaction of $\mathrm{NO}_{2}$ on soot (R2) effectively improved the model performance with regard to nighttime $\mathrm{HONO}$, but tended to enhance $\mathrm{HNO}_{3}$ and nitrate. Through a series of sensitivity simulations, a $\gamma_{\mathrm{HNO}_{3}}$ of 3.0 $\times 10^{-3}$ and $\gamma_{\text {HONO }}$ of $1 \times 10^{-4}$ were suggested for southern China in fall. A 3-D simulation using a chemical transport model with suggested uptake coefficients further confirmed that the two heterogeneous reactions had a noticeable effect on $\mathrm{HNO}_{3}$, nitrate, $\mathrm{NO}_{x}$, and HONO in the whole of southern China. Studies investigating the seasonal cycles and interannual variability of the impacts of heterogeneous reactions on $\mathrm{HNO}_{3}$ and nitrate are being conducted and will be the subject of a future paper. 


\section{Acknowledgements}

This research was supported by the Chinese Key Projects in the National Science \& Technology Pillar Program (2014BAC06B 03), the National Key Project of Basic Research (2014CB447900), the Chinese Academy of Sciences Strategic Priority Research Program (XDB05030101 and XDA05100501), China Ministry of Environmental Protection's Special Funds for Scientific Research on Public Welfare (201309016), and the Natural Science Foundation of China (41275138).

Edited by: D. Zhang

\section{Supplement}

The supplement describes the location of the Kaiping site and its meteorological parameters during the study period. Heterogeneous reactions in the study are also shown.

\section{References}

Adon, M., C. Galy-Lacaux, C. Delon, V. Yoboue, F. Solmon, and A. T. Kaptue Tchuente, 2013: Dry deposition of nitrogen compounds $\left(\mathrm{NO}_{2}, \mathrm{HNO}_{3}, \mathrm{NH}_{3}\right)$, sulfur dioxide and ozone in west and central African ecosystems using the inferential method. Atmos. Chem. Phys., 13, 11351-11374, doi:10.5194/acp-13-11351-2013.

Chatfield, R., 1994: Anomalous $\mathrm{HNO}_{3} / \mathrm{NO}_{\mathrm{x}}$ ratio of remote tropospheric air: Conversion of nitric acid to formic acid and $\mathrm{NO}_{\mathrm{x}}$ ? Geophys. Res. Lett., 21, 2705-2708.

Cheng, P., Y. Cheng, K. Lu, H. Su, Q. Yang, Y. Zou, Y. Zhao, H. Dong, L. Zeng, and Y. Zhang, 2013: An online monitoring system for atmospheric nitrous acid (HONO) based on stripping coil and ion chromatography. J. Environ. Sci., 25: 895-907.

Day, D. A., D. K. Farmer, A. H. Goldstein, P. J. Wooldridge, C. Minejima, and R. C. Cohen, 2009: Observations of $\mathrm{NO}_{\mathrm{x}}, \Sigma \mathrm{PNs}$, $\Sigma$ ANs, and $\mathrm{HNO}_{3}$ at a Rural Site in the California Sierra Nevada Mountains: summertime diurnal cycles. Atmos. Chem. Phys., 9, 4879-4896, doi:10.5194/acp-9-4879-2009.

Dong, H. B., L. M. Zeng, M. Hu, Y. S. Wu, Y. H. Zhang, J. Slanina, M. Zheng, M., Z. F. Wang, and R. Jansen, 2012: Technical Note: The application of an improved gas and aerosol collector for ambient air pollutants in China. Atmos. Chem. Phys., 12, 1051910533, doi:10.5194/acp-12-10519-2012.

Han, K. M., S. Lee, L. S. Chang, and C. H. Song, 2015: A comparison study between CMAQ-simulated and OMI-retrieved $\mathrm{NO}_{2}$ columns over East Asia for evaluation of $\mathrm{NO}_{\mathrm{x}}$ emission fluxes of INTEX-B, CAPSS, and REAS inventories. Atmos. Chem. Phys., 15, 1913-1938, doi:10.5194/acp-15-1913-2015.

Hauglustaine, D. A., B. A. Ridley, S. Solomon, P. G. Hess, and S. Madronich, 1996: $\mathrm{HNO}_{3} / \mathrm{NO}_{\mathrm{x}}$ ratio in the remote troposphere during MLOPEX 2: Evidence for nitric acid reduction on carbonaceous aerosols? Geophys. Res. Lett., 23, 2609-2612.

Jansen, R., Y. Shi, J. Chen, Y. Hu, C. Xu, S. Hong, J. Li, and M. Zheng, 2014: Using hourly measurements to explore the role of secondary inorganic aerosol in $\mathrm{PM}_{2.5}$ during haze and fog in Hangzhou, China. Adv. Atmos. Sci., 31, 1427-1434.

Kim, J. Y., C. H. Song, Y. S. Ghim, J. G. Won, S. C. Yoon, G. R. Carmichael, and H. H. Woo, 2006: An investigation on $\mathrm{NH}_{3}$ emissions and particulate $\mathrm{NH}_{4}^{+}-\mathrm{NO}_{3}{ }^{-}$formation in East Asia. Atmos. Environ., 40, 2139-2150.

Kleffmann, J., and P. Wiesen, 2005: Heterogeneous conversion of $\mathrm{NO}_{2}$ and $\mathrm{NO}$ on $\mathrm{HNO}_{3}$ treated soot surfaces: atmospheric implications. Atmos. Chem. Phys., 5, 77-83, doi:10.5194/acp-5-772005.

Li, Y., J. An, M. Kajino, J. Li, and Y. Qu, 2015: Impacts of additional HONO sources on concentrations and deposition of $\mathrm{NO}_{\mathrm{y}}$ in the Beijing-Tianjin-Hebei region of China. SOLA, 11, 36-42.

Li, J., Z. Wang, and W. Xiang, 2011: Daytime atmospheric oxidation capacity of urban Beijing under polluted conditions during the 2008 Beijing Olympic Games and the impact of aerosols. SOLA, 7, 73-76, doi:10.2151/sola.2011-019.

Li, J., Z. Wang, G. Zhuang, G. Luo, Y. Sun, and Q. Wang, 2012a:
Mixing of Asian mineral dust with anthropogenic pollutants over East Asia: a model case study of a super-duststorm in March 2010. Atmos. Chem. Phys., 12, 7591-7607, doi:10.5194/ acp-12-7591-2012.

Li, X., T. Brauers, R. Häseler, B. Bohn, H. Fuchs, A. Hofzumahaus, F. Holland, S. Lou, K. D. Lu, F. Rohrer, M. Hu, L. M. Zeng, Y. H. Zhang, R. M. Garland, H. Su, A. Nowak, A. Wiedensohler, N. Takegawa, M. Shao, and A. Wahner, 2012b: Exploring the atmospheric chemistry of nitrous acid (HONO) at a rural site in Southern China. Atmos. Chem. Phys., 12, 1497-1513, doi: 10.5194/acp-12-1497-2012.

Michoud, V., A., Colomb, A. Borbon, K. Miet, M. Beekmann, M. Camredon, B. Aumont, S. Perrier, P. Zapf, G. Siour, W. AitHelal, C. Afif, A. Kukui, A., M. Furger, J. C. Dupont, M. Haeffelin, and J. F. Doussin, 2014: Study of the unknown HONO daytime source at a European suburban site during the MEGAPOLI summer and winter field campaigns. Atmos. Chem. Phys., 14, 2805-2822, doi:10.5194/acp-14-2805-2014.

Muñoz, M. S., and M. J. Rossi, 2002: Heterogeneous reactions of $\mathrm{HNO}_{3}$ with flame soot generated under different combustion conditions. Reaction mechanism and kinetics. Phys. Chem. Chem. Phys., 4: 5110-5118, doi:10.1039/b203912.

Rogaski, C. A., D. M. Golden, and L. R. Williams, 1997: Reactive uptake and hydration experiments on amorphous carbon treated with $\mathrm{NO}_{2}, \mathrm{SO}_{2}, \mathrm{O}_{3}, \mathrm{HNO}_{3}$ and $\mathrm{H}_{2} \mathrm{SO}_{4}$. Geophys. Res. Lett., 24, 381-384.

Saathoff, H., K.-H. Naumann, N. Riemer, S. Kamm, O. Möhler, U. Schurath, H. Vogel, and B. Vogel, 2001: The loss of $\mathrm{NO}_{2}, \mathrm{HNO}_{3}$, $\mathrm{NO}_{3} / \mathrm{N}_{2} \mathrm{O}_{5}$, and $\mathrm{HO}_{2} / \mathrm{HOONO}_{2}$ on soot aerosol: A chamber and modeling study. Geophys. Res. Lett., 1957-1960, doi:10.1029/ 2000GL012619.

Shao, M., S. H. Lu, Y. Liu, X. Xie, C. C. Chang, S. Huang, and Z. M. Chen, 2009: Volatile organic compounds measured in summer in Beijing and their role in ground-level ozone formation. J. Geophys. Res.-Atmos., 114, D00G06, doi:10.1029/2008jd010863.

Shimadera, H., H. Hayami, S. Chatani, Y. Morino, Y. Mori, T. Morikawa, K. Yamaji, and T. Ohara, 2014: Sensitivity analyses of factors influencing CMAQ performance for fine particulate nitrate. J. Air Waste Manag. Assoc., 64, 374-387.

Sudo, K., M. Takahashi, and H. Akimoto, 2002: CHASER: A global chemical model of the troposphere 2. Model results and evaluation. J. Geophys. Res., 107, doi:10.1029/2001/JD001114.

Talbot, R., J. Dibb, E. Scheuer, G. Seid, R. Russo, S. Sandholm, D. Tan, H. Singh, D. Blake, E. Atlas, G. Sachse, C. Jordan, and M. Avery, 2003: Reactive nitrogen in Asian continental outflow over the western Pacific: Results from the NASA Transport and Chemical Evolution over the Pacific (TRACE-P) airborne mission. J. Geophys. Res., 108, D20, 8803, doi:10.1029/2002JD 003129.

Tang, Y., J. An, Y. Li, F. Wang, and co-authors, 2014: Uncertainty in the uptake coefficient for HONO formation on soot and its impacts on concentrations of major chemical components in the Beijing-Tianjin-Hebei region. Atmos. Environ., 84, 163-171.

Tie, X., S. Madronich, S. Walters, D. P. Edwards, P. Ginous, N. Mahowald, R. Zhang, C. Lou, and G. Brasseur, 2005: Assessment of the global impact of aerosols on tropospheric oxidants. $J$. Geophys. Res., 110, D03204, doi:10.1029/2004JD005359.

Wang, Y., Q. Zhang, K. He, Q. Zhang, and L. Chai, 2013: Sulfatenitrate-ammonium aerosols over China: response to 2000-2015 emission changes of sulfur dioxide, nitrogen oxides, and ammonia. Atmos. Chem. Phys., 13, 2635-2652.

Zhang, Q., D. G. Streets, G. R., Carmichael, K. B. He, H. Huo, A. Kannari, Z. Klimont, I. S. Park, S. Reddy, J. S. Fu, D. Chen, L. Duan, Y. Lei, L. T. Wang, and Z. L. Yao, 2009a: Asian emissions in 2006 for the NASA INTEX-B mission. Atmos. Chem. Phys., 9, 5131-5153, doi:10.5194/acp-9-5131-2009.

Zhang, Y. H., 2009b: An Overview of the 3C-STAR project. Geophys. Res. Abstr., 11, EGU2009-3870.

Zheng, J., R. Zhang, E. C. Fortner, R. M. Volkamer, L. Molina, A. C. Aiken, J. L. Jimenez, K. Gaeggeler, J. Dommen, S. Dusanter, P. S. Stevens, and X. Tie, 2008: Measurements of $\mathrm{HNO}_{3}$ and $\mathrm{N}_{2} \mathrm{O}_{5}$ using ion drift-chemical ionization mass spectrometry during the MILAGRO/MCMA-2006 campaign. Atmos. Chem. Phys., 8, 6823-6838, doi:10.5194/acp-8-6823-2008.

Manuscript received 6 August 2015, accepted 18 September 2015 SOLA: https://www.jstage.jst.go.jp/browse/sola/ 